\title{
ANALISIS FAKTOR-FAKTOR YANG MEMPENGARUHI KEPUTUSAN PEMBELIAN DI KEDAI KOPI LOKAL KOTA MATARAM
}

\section{ANALYSIS OF FACTORS THAT INFLUENCE PURCHASING DECISIONS AT COFFEE SHOPS CITY OF MATARAM}

\author{
Hendra Juniard ${ }^{1 *}$, Addinul Yakin ${ }^{2}$, Tajidan $^{2}$ \\ ${ }^{1}$ Program Studi Agribisnis Fakultas Pertanian Universitas Mataram, Mataram, Indonesia \\ ${ }^{2}$ Program Studi Agribisnis Fakultas Pertanian Universitas Mataram, Mataram, Indonesia \\ *Email Penulis korespondensi: hendrajuniardi@gmail.com
}

\begin{abstract}
Abstrak
Penelitian bertujuan untuk: (1) Menganalisis seberapa besar dan bagaimana pengaruh jenis kelamin terhadap keputusan pembelian di Kedai Kopi di Kota Mataram; (2) Menganalisis seberapa besar dan bagaimana pengaruh umur terhadap keputusan pembelian di Kedai Kopi di Kota Mataram; (3) Menganalisis seberapa besar dan bagaimana pengaruh tingkat pendidikan terhadap keputusan pembelian di Kedai Kopi di Kota Mataram; (4) Menganalisis seberapa besar pengaruh tingkat pendapatan terhadap keputusan pembelian di Kedai Kopi di Kota Mataram; (5) Menganalisis seberapa besar dan bagaimana pengaruh store atmosphere terhadap keputusan pembelian di Kedai Kopi di Kota Mataram; (6) Menganalisis seberapa besar dan bagaimana pengaruh harga terhadap keputusan pembelian di Kedai Kopi di Kota Mataram; (7) Menganalisis seberapa besar dan bagaimana pengaruh lokasi terhadap keputusan pembelian di Kedai Kopi di Kota Mataram; (8) Menganalisis seberapa besar pengaruh dan bagaimana kualitas produk terhadap keputusan pembelian di Kedai Kopi di Kota Mataram. Hasil penelitian menunjukkan bahwa; (1) Jenis Kelamin (X1) tidak berpengaruh nyata terhadap keputusan pembelian konsumen di kedai kopi di Kota Mataram. (2) Umur (X2) berpengaruh positif terhadap keputusan pembelian kopi di kedai kopi di Kota Mataram. (3) Pendidikan (X3) berpengaruh negatif terhadap keputusan pembelian kopi di kedai kopi di Kota Mataram. (4) Pendapatan (X4) berpengaruh positif terhadap keputusan pembelian kopi di kedai kopi di Kota Mataram. (5) Store Atmosphere (X5) berpengaruh positif terhadap keputusan pembelian kopi di kedai kopi di Kota Mataram. (6) Harga (X6) berpengaruh positif terhadap keputusan pembelian kopi di kedai kopi di Kota Mataram. (7) Lokasi (X7) berpengaruh positif terhadap keputusan pembelian kopi di kedai kopi di Kota Mataram. (8) Kualitas Produk (X8) berpengaruh positif terhadap keputusan pembelian kopi di kedai kopi di Kota Mataram.

Kata kunci : Keputusan Pembelian, Faktor-Faktor, Kedai Kopi di Kota Mataram
\end{abstract}

\begin{abstract}
The research aims to: (1) Analyze how much and how gender influences purchasing decisions at Coffeeshop in Mataram City; (2) Analyze how much and how ages influence on purchasing decisions at coffeeshops in Mataram City; (3) Analyzing how much and how the influence of education level on purchasing decisions at coffee shops in Mataram City; (4) Analyze how much influence the level of income on purchasing decisions at coffee shops in Mataram City; (5) Analyzing the extent and influence of store atmosphere on purchasing decisions at coffee shops in Mataram City; (6) Analyzing how much and how the influence of prices on purchasing decisions at coffee shops in Mataram City; (7) Analyzing the extent and influence of location on purchasing decisions at coffee shops in Mataram City; (8) Analyze how much influence and how the quality of the product on purchasing decisions at the coffee shops in MataramCity. The results showed that; (1) Gender (XI) does not significantly affect consumer purchasing decisions in coffee shops in the city of Mataram. (2) Ages (X2) has a positive effect on coffee purchasing decisions in coffee shops in the city of Mataram. (3) Education (X3) negatively influences coffee purchasing decisions in coffee shops in the city of Mataram. (4) Revenue (X4) has a positive effect on coffee purchasing decisions in coffee shops in the city of Mataram. (5) Store Atmosphere (X5) has a positive effect on coffee purchasing decisions in coffee shops in the city of Mataram. (6) Price (X6) has a positive effect on coffee purchasing decisions in coffee shops in the city of Mataram. (7) Location (X7) has a positive effect on coffee purchasing decisions in coffee shops in the city of Mataram. (8) Product Quality (X8) has a positive effect on coffee purchasing decisions in coffee shops in the city of Mataram. Keywords: Purchasing Decisions, Factors, Coffee Shops in the City of Mataram
\end{abstract}




\section{PENDAHULUAN}

Indonesia merupakan negara agraris yang kaya akan sumber daya alam, terutama di sektor pertanian dan perkebunan, yang menjadi salah satu sektor andalan sejak lama. Hal ini dikarenakan bahwa sektor pertanian masih memiliki peran penting dan strategis dalam pembangunan dan perekonomian nasional (Nursan \& Septiadi, 2020). Selain itu, Potensi di bidang pertanian dan perkebunan ini membuka peluang terbukanya sektor baru untuk dikembangkan, yaitu industri pangan baik itu makanan maupun minuman. Pesatnya perkembangan ilmu pengetahuan dan teknologi mendorong kemajuan industri pangan semakin kreatif dan inovatif, dimana para pelakunya mampu meningkatkan kualitas serta berinovasi pada produk yang diciptakan.

Salah satu komoditas yang industrinya semakin maju saat ini adalah tanaman kopi. Kopi merupakan produk perkebunan yang biasanya diolah menjadi minuman, dinikmati hampir oleh semua kalangan di seluruh dunia. Indonesia sendiri merupakan salah satu negara dengan konsumsi kopi terbesar di dunia. Data International Coffee Organization (ICO) mencatat konsumsi kopi Indonesia periode 2016/2017 mencapai 4,6 juta kemasan $60 \mathrm{~kg} / \mathrm{lb}(60 \mathrm{~kg})$ berada di urutan ke-6 negara dengan konsumsi kopi terbesar di dunia di bawah Rusia. (databoks.katadata.co.id) diakses pada 22 Oktober 2019.

Salah satu faktor yang menyebabkan peningkatan konsumsi tersebut adalah banyaknya kedai kopi modern baik franchise dari luar daerah maupun kedai kopi lokal, sehingga masyarakat lebih mudah mengakses dan mendapatkan minuman kopi di sekitarnya. Menjamurnya kafe-kafe yang menjajakan minuman maupun kopi kemasan dapat meningkatkan konsumsi minuman hasil olahan biji kopi nasional. Selain menaikkan nilai jual, munculnya kedai-kedai tersebut juga bakal mendorong tumbuhnya ekonomi kreatif dari komoditas kopi, baik untuk pasar domestik maupun ekspor. (databoks.katadata.co.id) diakses pada 22 Oktober 2019.

Definisi kedai kopi atau coffee shop itu sendiri menurut Wiktionary (2010) bisa diartikan sebuah cafe kecil atau restoran kecil yang biasanya menjual kopi dan terkadang minuman non-alkohol, makanan sederhana atau snacks, dengan fasilitas yang menunjang di tempat tersebut. Begitu juga menurut Anik (2009) pengertian coffee shop atau warung kopi sendiri dalam kamus besar Bahasa Indonesia karya Poerwadarminta adalah sebuah tempat yang menjual kopi dan jenis minuman lain, serta makananmakanan kecil dengan berbagai kisaran harga.

Pertumbuhan industri kopi ini tidak hanya terjadi di kota-kota besar, melainkan juga terjadi di Provinsi Nusa Tenggara Barat. Di Kota Mataram sendiri sudah terdapat banyak sekali kedai kopi modern yang menyediakan berbagai jenis minuman kopi dengan berbagai varian harga, varian rasa dan jenis kopi, serta suasana kedai yang berbeda, yang tersebar hampir di seluruh wilayah di kota Mataram. Pesatnya pertumbuhan bagi industri ini dengan berbagai ciri khasnya memberikan banyak alternatif dan ragam pilihan bagi konsumen, terutama para pencinta kopi di Kota Mataram.

Hasil penelitian oleh Endang Wiji Lestari, Idha Haryanto, dan Surip Mawardi (2009) menunjukkan bahwa rata-rata konsumsi kopi perorangan 2,91 kg/tahun, konsumsi kopi pada laki-laki 3,83 kg/tahun dan perempuan 1,97 kg/tahun. Konsumsi kopi perorangan sangat dipengaruhi oleh faktor jenis kelamin, umur, pendapatan, harga, aktivitas dan konsumsi rokok. Tingkat konsumsi pada perempuan dipengaruhi secara nyata oleh faktor umur, harga dan konsumsi rokok. Tingkat konsumsi kopi masyarakat 
sulit dipastikan karena keragaman dalam mengkonsumsi minuman ini. Untuk mengetahui tingkat konsumsi kopi dilakukan pendekatan melalui konsumsi jenis kopi olahan dan frekuensi konsumsi.Sedangkan menurut penelitian oleh Anggun Zuhrufanina, keputusan pembelian minuman kopi dipengaruhi oleh faktor-faktor eksternal seperti store atmosphere, lokasi, harga dan kualitas produk.

Salah satu faktor yang disebutkan adalah Store Atmosphere atau suasana toko. Menurut Levy \& Weitz (2012), Atmosfer mengacu pada desain lingkungan seperti komunikasi visual, pencahayaan, warna, musik, dan aroma untuk mensimulasikan respon persepsi dan emosi pelanggan dan pada akhirnya mempengaruhi perilaku pembelian mereka. Sedangkan menurut Sutisna (2001), Store Atmosphere adalah penataan ruang dalam (instore) dan ruang luar (outstore) yang dapat menciptakan kenyamanan bagi pelanggan. Dengan Store Atmosphere yang tepat, akan hadir nuansa atmosphere dan estetika yang menarik pengunjung untuk menentukan pilihannya dan melaksanakan keputusan pembelian (Danang, 2015).

Harga adalah jumlah uang (ditambah beberapa barang kalau mungkin) yang dibutuhkan untuk mendapatkan sejumlah kombinasi dari barang beserta pelayanannya (Swastha, 2003). Atau singkatnya, harga adalah sejumlah uang atau korbanan yang kita berikan untuk mendapatkan barang dan atau jasa yang kita inginkan.Seorang konsumen biasanya cenderung memilih barang sejenis dengan harga yang lebih murah daripada barang yang lebih mahal. Sehingga, disini harga juga memiliki pengaruh terhadap keputusan pembelian.

Lokasi dalam hal ini merupakan tempat suatu bisnis dijalankan, beberapa hal yang harus dipertimbangkan dalam memilih lokasi ialah kemudahan untuk dijangkau, ketersediaan sarana dan prasarana transportasi, serta ketersediaan lahan parkir bagi pelanggan. Jadi, seorang konsumen lebih cenderung memilih tempat yang dekat dan mudah dijangkau dari tempat ia berada.

Kualitas Produk adalah Kemampuan suatu produk untuk melaksanakan fungsinya meliputi daya tahan, keandalan, ketepatan, kemudahan operasi dan perbaikan, serta atribut bernilai lainnya. Dalam kasus ini, kualitas produk juga meliputi rasa, variasi, inovasi dan porsi.Suatu produk yang berkualitas biasanya sesuai dengan harganya. Kualitas suatu produk dikatakan baik bagi konsumen jika konsumen merasakan produk yang didapatkan setara dengan sejumlah uang yang ia bayar. Cita rasa suatu produk kopi sangat sensitif bagi sebagian konsumen, hal ini karena perbedaan selera dan kecintaan pada kopi itu sendiri.Selain itu, varian rasa dan jenis kopi yang beragam juga memicu konsumen untuk terus mengkonsumsi kopi. Berdasarkan beberapa uraian di atas, maka peneliti tertarik untuk melakukan penelitian dengan judul "Analisis Faktor-faktor Yang Mempengaruhi Keputusan Pembelian di Kedai Kopi di Kota Mataram.

\section{METODE PENELITIAN}

Metode yang digunakan dalam penelitian ini adalah metode diskriptif (Sugiono, 2017). Unit analisis pada penelitian ini ialah Keputusan Pembelian Konsumen pada Kedai Kopi di Kota Mataram. Penentuan daerah sampel menggunakan Purposive Sampling di 5 kedai kopi di Kota Mataram yang sebelumnya telah disurvei dengan beberapa kriteria yaitu kedai kopi lokal, memiliki bangunan permanen, memiliki instore dan outstore, serta mengolah biji kopi secara modern dengan mesin kopi. Kedai kopi yang dipilih yaitu: Soetjipto, Kota Tua Kopi, Maktal Coffee Bar, Acibara Coffee, dan Warpindo. Penentuan jumlah responden menggunakan Quota Sampling, dimana jumlah 
responden dalam penelitian ini ialah sebanyak 100 orang, dengan masing-masing 20 responden dari tiap lokasi penelitian. Penentuan sampel responden dalam penelitian ini menggunakan Accidental Random Sampling. Dimana reponden yang dipilih ialah konsumen yang peneliti temui di kedai kopi terkait. Responden yang dimaksud ialah konsumen yang datang ke Kedai Kopi dan membeli produk kopi, artinya konsumen yang ke kedai kopi namun tidak membeli kopi tidak termasuk responden.

Jenis data yang digunakan dalam penelitian ini adalah data kualitatif dan data kuantitatif. Sumber data yang digunakan dalam penelitian ini adalah Data primer dan data sekunder. Variabel yang diukur dalam penelitian ini adalah (1) Jenis Kelamin (2) Umur (3) Pendidikan (4) Pendapatan (5) Store Atmosphere (6) Harga (7) Lokasi (8) Kualitas Produk, dan (9) Keputusan Pembelian

\section{Uji Regresi Berganda}

Alat analisis yang digunakan dalam penelitian ini adalah analisis regresi linear berganda. Analisis regresi linear berganda digunakan untuk satu variabel dependen dan beberapa variabel independen.

$\mathrm{Y}=\mathrm{a}+\mathrm{Db}_{1} \mathrm{X}_{1}+\mathrm{b}_{2} \mathrm{X}_{2}+\mathrm{b}_{3} \mathrm{X}_{3}+\mathrm{b}_{4} \mathrm{X}_{4}+\mathrm{b}_{5} \mathrm{X}_{5}+\mathrm{b}_{6} \mathrm{X}_{6}+\mathrm{b}_{7} \mathrm{X}_{7}+\mathrm{b}_{8} \mathrm{X}_{8}$

Keterangan :

$\mathrm{Y}=$ Keputusan Pembelian Kopi

$\mathrm{a}=$ Intersep

$\mathrm{b}=$ Koefisien regresi untuk variabel 1,2,3,4,5,6,7,8

$\mathrm{D}=$ Dummy Variabel

$\mathrm{X}_{1}=$ Jenis Kelamin (Laki-laki/Perempuan)

$\mathrm{X}_{2}=$ Umur (Tahun)

$\mathrm{X}_{3}=$ Tingkat Pendidikan (Pendidikan terakhir)

$\mathrm{X}_{4}=$ Tingkat Pendapatan $(\mathrm{Rp} /$ bulan $)$

$\mathrm{X}_{5}=$ Variabel Store Atmosphere (Skor)

$\mathrm{X}_{6}=$ Variabel Harga (Skor)

$\mathrm{X}_{7}=$ Variabel Lokasi (Skor)

$\mathrm{X}_{8}=$ Variabel Kualitas Produk (Skor)

\section{Uji F}

Uji statistik F digunakan untuk mengetahui apakah semua variabel independen secara bersama-sama memiliki pengaruh nyata terhadap variabel dependen. Dalam penelitian ini yaitu pengaruh variabel Jenis Kelamin, Umur, Store Atmosphere, Harga, Lokasi Dan Kualitas Produk terhadap variabel Keputusan Pembelian. Pengujian dilakukan dengan membandingkan antara $\mathrm{F}$ hitung dan $\mathrm{F}$ tabel dengan signifikansi sebesar 0,05 .

Apabila $\mathrm{F}$ tabel $>\mathrm{F}$ hitung maka Ho diterima dan Ha ditolak.

Apabila $\mathrm{F}$ tabel $<\mathrm{F}$ hitung, maka Ho ditolak dan Ha diterima.

Uji Koefisien Determinasi $\left(\mathbf{R}^{2}\right)$

Determinasi digunakan untuk melihat seberapa besar kemampuan model dalam menerangkan variabel terikat.Jika (R2) semakin besar atau mendekati satu, maka dapat disimpulkan bahwa pengaruh variabel bebas (X1, X2, X3, X4, X5, X6, X7 dan X8) adalah besar terhadap variabel terikat $(Y)$. Hal ini berarti model yang digunakan semakin kuat untuk menerangkan pengaruh variabel bebas yang diteliti terhadap variabel terikat. Sebaliknya jika determinasi (R2) semakin mengecil atau mendekati angka nol maka dapat dikatakan bahwa pengaruh variabel bebas (X1, X2, X3, X4, X6, $\mathrm{X} 7$, dan X8) terhadap variabel terikat semakin mengecil. Hal ini berarti model yang 
digunakan tidak kuat untuk menerangkan pengaruh variabel bebas yang diteliti terhadap variabel terikat.

\section{HASIL DAN PEMBAHASAN}

\section{Hasil Uji Regresi Berganda}

Tujuan analisis ini adalah untuk mengetahui apakah tiap-tiap variabel independen berpengaruh nyata terhadap variabel dependen dan seberapa besar variablevariabel independen tersebut dalam mempengaruhi variable dependen.

Dirumuskan sebagai berikut: $\mathrm{Y}=\mathrm{a}+\mathrm{Db}_{1} \mathrm{X}_{1}+\mathrm{b}_{2} \mathrm{X}_{2}+\mathrm{b}_{3} \mathrm{X}_{3}+\mathrm{b}_{4} \mathrm{X}_{4}+\mathrm{b}_{5} \mathrm{X}_{5}+\mathrm{b}_{6} \mathrm{X}_{6}+\mathrm{b}_{7} \mathrm{X}_{7}+\mathrm{b}_{8} \mathrm{X}_{8}$

Berikut hasil analisis regresi berganda dengan SPSS:

Tabel 1. Hasil Uji Analisis Regresi Berganda

\begin{tabular}{lccc}
\hline \multicolumn{1}{c}{ Variabel } & Nilai Koefisien & t-hitung & Sig \\
\hline Konstanta & -34.546 & -7.187 & 0.000 \\
Jenis Kelamin & 1.345 & 1.033 & 0.304 \\
Umur & 2.122 & 2.229 & 0.028 \\
Pendidikan & -2.025 & -2.124 & 0.036 \\
Pendapatan & 1.212 & 2.047 & 0.044 \\
Store Atmosphere & 0.180 & 2.056 & 0.043 \\
Harga & 0.495 & 2.180 & 0.032 \\
Lokasi & 0.953 & 3.264 & 0.002 \\
Kualitas Produk & 0.875 & 2.682 & 0.009 \\
\hline
\end{tabular}

Sumber: Data Primer diolah, 2020

\section{Jenis Kelamin}

Nilai koefisien regresi variabel jenis kelamin (X1) adalah sebesar 1,345, artinya setiap penambahan 1 konsumen laki-laki, maka variabel keputusan pembelian akan meningkat sebesar 1,345 jika variabel lain dianggap tetap, tetapi variabel jenis kelamin tidak berpengaruh nyata terhadap keputusan pembelian.

Hal ini sesuai dengan hasil penelitian Endang Wiji Lestari, Idha Haryanto, dan Surip Mawardi (2009) "Konsumsi Kopi Masyarakat Perkotaan dan Faktor-Faktor yang Berpengaruh: Kasus di Kabupaten Jember" yang menjelaskan bahwa faktor jenis kelamin mempunyai hubungan positif dengan tingkat konsumsi kopi tetapi tidak berpengaruh signifikan terhadap tingkat konsumsi kopi. Hal ini didasarkan pada kenyataan bahwa konsumsi makanan tidak membedakan jenis kelamin. Dengan demikian konsumsi kopi tidak didominasi oleh salah satu jenis kelamin saja, mengingat sifat kopi adalah sebagai makanan (food) yang mempunyai aspek kepuasan dan kenikmatan.

\section{Umur}

Nilai signifikansi variabel umur (X2) adalah sebesar 0,028 $<0,05$ maka H0 ditolak dan Ha diterima, artinya jika variabel lain dianggap tetap, maka variabel umur berpengaruh nyata terhadap keputusan pembelian. Nilai koefisien regresi variabel umur 
(X2) adalah sebesar 2,122, maka setiap peningkatan satu-satuan umur akan meningkatkan Variabel Keputusan Pembelian sebesar 2,122.

Hasil tersebut sesuai dengan teori konsumsi hipotesis siklus hidup (Life Cycle Hypothesis) yang dikembangkan oleh Franco Modigliani, Albert Ando, dan Richard Brumberg mengenai pengeluaran konsumsi masyarakat berdasarkan kepada pola penerimaan dan pola pengeluaran konsumsi seseorang pada umumnya dipengaruhi oleh masa dalam siklus hidupnya (usia). Semakin tua umur seseorang maka semakin tinggi pula tingkat konsumsi yang dimiliki orang tersebut, begitu juga sebaliknya.

Hasil penelitian ini juga sesuai dengan hasil penelitian Endang Wiji Lestari, Idha Haryanto, dan Surip Mawardi (2009) pada jurnalnya "Konsumsi Kopi Masyarakat Perkotaan dan Faktor-Faktor yang Berpengaruh: Kasus di Kabupaten Jember" yang menunjukkan bahwa umur berpengaruh signifikan terhadap tingkat konsumsi kopi. Pola konsumsi seseorang akan mempengaruhi perilaku konsumsi, dan salah satu faktor yang mempengaruhi konsumsi kopi adalah umur. Hal ini didukung pula pendapat Andriani (2000), bahwa tingkat konsumsi dipengaruhi oleh karakteristik umur, jenis kelamin, pendidikan dan pekerjaan.

\section{Pendidikan}

Nilai signifikansi variabel pendidikan (X3) adalah sebesar 0,036 $<0,05$ maka H0 ditolak dan Ha diterima, artinya jika variabel lain dianggap tetap, maka variabel pendidikan berpengaruh nyata terhadap keputusan pembelian. Nilai koefisien regresi variabel pendidikan (X3) adalah sebesar -2,025, artinya setiap peningkatan satu-satuan pendidikan akan menurunkan keputusan pembelian sebesar -2,025.

Hasil dari penelitian ini belum bisa dipastikan, karena hal tersebut tidak sesuai dengan penelitian Mizfar dan Sinaga (2015) yang menyatakan bahwa faktor tingkat pendidikan memiliki hubungan positif terhadap konsumsi kopi seseorang. Namun di sisi lain pola konsumsi ini memiliki hubungan dengan preferensi menabung seseorang. Menurut Nurasiah (2018) pendidikan memiliki pengaruh positif terhadap minat beli produk bank syariah. Dengan pencapaian pendidikan yang tinggi, membuat seseorang memiliki pengetahuan yang baik mengenai masalah dan informasi keuangan. Sehingga akan lebih efektif dalam pengambilan keputusan. Jadi, hasil penelitian tersebut menunjukkan bahwa seseorang dengan tingkat pendidikan tinggi akan cenderung memilih untuk menabung.

\section{Pendapatan}

Nilai signifikansi variabel pendapatan (X4) adalah sebesar $0,044<0,05$ maka H0 ditolak dan Ha diterima, artinya jika variabel lain dianggap tetap, maka variabel pendapatan berpengaruh nyata terhadap keputusan pembelian. Nilai koefisien regresi variabel pendapatan (X4) adalah sebesar 1,212, artinya setiap peningkatan satu-satuan pendapatan akan meningkatkan keputusan pembelian sebesar 1,212.

Hasil penelitian ini sesuai dengan teori konsumsi menurut John Maynard Keynes mengenai konsumsi seorang individu saat ini (current income) berhubungan langsung dengan pendapatan disposable yang diperoleh pada saat ini (current disposable income). Semakin tinggi pendapatan seseorang maka semakin tinggi pula tingkat konsumsinya, begitu juga sebaliknya. Hal ini tentu berhubungan langsung dengan keputusan pembelian seseorang.

Menurut Sukirno (2005) menyatakan hubungan antara pendapatan dengan konsumsi adalah hubungan yang searah (proposional) maksudnya pada pendapatan yang lebih tinggi dapat menyebabkan pengeluaran konsumsi lebih besar dan demikian juga sebaliknya yaitu bila tingkat pendapatan rendah maka pengeluaran konsumsi juga rendah. 
Hasil penelitian ini juga sesuai dengan penelitian yang dilakukan oleh Endang Wiji Lestari, Idha Haryanto, dan Surip Mawardi (2009) "Konsumsi Kopi Masyarakat Perkotaan dan Faktor-Faktor yang Berpengaruh: Kasus di Kabupaten Jember" yang menunjukkan bahwa konsumsi kopi perorangan sangat dipengaruhi oleh beberapa faktor salah satunya adalah pendapatan yang dimilikinya.

\section{Store Atmosphere}

Nilai signifikansi variabel store atmosphere (X5) adalah sebesar 0,043<0,05, maka $\mathrm{H} 0$ ditolak dan Ha diterima, artinya jika variabel lain dianggap tetap, maka variabel store atmosphere berpengaruh nyata terhadap keputusan pembelian. Nilai koefisien regresi variabel store atmosphere (X5) adalah sebesar 0,180, artinya setiap peningkatan satu-satuan store atmosphere akan meningkatkan keputusan pembelian sebesar 0,180.

Store Atmosphere memiliki 4 indikator yaitu exterior, interior, general interior dan store layout. Exterior meliputi papan nama toko yang terlihat jelas, tempat parkir yang luas dan aman, dan pintu masuk kedai kopi yang luas. Interior meliputi pemilihan tema dan konsep toko dan pemasangan petunjuk atau hiasan di dalam toko. General interior meliputi aroma ruangan, suhu ruangan yang sejuk, pencahayaan toko yang menarik, musik, pemilihan perabot dan pewarnaan pada bagian dalam toko. Store layout meliputi penataan perabot seperti kursi dan meja sehingga memudahkan akses konsumen di dalam kedai kopi dan penataan barang lainnya. Ketika keempat indikator tersebut semakin ditingkatkan, maka akan meningkatkan keputusan pembelian konsumen, karena store atmosphere tidak hanya membuat konsumen merasa betah, tetapi juga membuat konsumen tertarik untuk melakukan pembelian ulang.

Ma'ruf (2006) mengatakan jika iklan bertujuan memberitahu,menarik, memikat, atau mendorong konsumen untuk datang ke gerai dan untuk membeli barang, maka suasana atau atmosfer dalam gerai berperan penting memikat pembeli, membuat nyaman mereka dalam memilih barang belanja, dan mengingatkan mereka produk apa yang perlu dimiliki baik untuk keperluan pribadi maupun untuk keperluan rumah tangga. Suasana yang dimaksud adalah dalam arti atmosfer dan ambience yang tercipta dari gabungan unsur-unsur desain toko/gerai, perencanaan toko (alokasi ruang, rencana gang, layout), komunikasi visual (identitas ritel, grafis), dan merchandising (penyajian merchandise).

Hasil penelitan ini menunjukkan bahwa semakin baik store atmosphere atau suasana toko di kedai kopi di Kota Mataram, maka dapat meningkatkan keputusan pembelian atau kunjungan konsumen. Sebaliknya jika suasana toko tidak baik, maka dapat menurangi keputusan pembelian atau kunjungan konsumen ke kedai kopi tersebut. Hal ini sesuai dengan hasil penelitian sebelumnya yang dilakukan oleh Melin Meidina Hutauruk (2012) "Pengaruh Store Atmosphere Terhadap Keputusan Pembelian Konsumen Chirurgie Café dan Books Medan" yang menunjukkan bahwa store atmosphere berpengaruh secara signifkan terhadap keputusan pembelian konsumen di Chirurgie Cafe and Books.

\section{Harga}

Nilai signifikansi variabel harga (X6) adalah sebesar $0,032<0,05$, maka H0 ditolak dan Ha diterima, artinya jika variabel lain dianggap tetap, maka variabel harga berpengaruh nyata terhadap keputusan pembelian. Nilai koefisien regresi variabel harga (X6) adalah 0,495, artinya setiap peningkatan satu-satuan harga, atau semakin baik kinerja harga, maka akan meningkatkan keputusan pembelian sebesar 0,495.

Harga merupakan suatu nilai produk, karna akan berpengaruh terhadap keuntungan produsen. Harga juga menjadi pertimbangan konsumen untuk membeli, 
sehingga perlu pertimbangan khusus untuk menentukan harga tersebut. Menurut Kotler dan Armstrong (2012), ada empat indikator yang harga yaitu: Keterjangkauan harga, kesesuaian harga dengan kualitas produk, daya saing harga, kesesuaian harga dengan manfaat. Sehingga jika keempat indikator tersebut dapat ditingkatkan, maka konsumen akan meningkatkan keputusan pembeliannya.

Hasil penelitian ini menunjukkan bahwa variabel harga berpengaruh positif terhadap keputusan pembelian, artinya semakin tinggi harga, maka semakin tinggi pula keputusan pembelian.Harga tinggi yang dimaksud dalam penelitian ini bukan berarti semakin mahal, tetapi sesuai dengan teori Kotler dan Armstrong di atas, yaitu berarti semakin terjangkau, semakin sesuai dengan kualitas, semakin bersaing dan semakin sesuai dengan manfaat yang dirasakan konsumen. Jadi, dalam penelitian ini, harga yang dimaksud bukan nilai riil dalam bentuk angka, tetapi kinerja harga terhadap kepuasan konsumen. Hasil penelitian ini sesuai dengan hasil penelitian dari Heni Fitri (2017) "Pengaruh Faktor Harga, Lokasi dan Kualitas Pelayanan Terhadap Keputusan Pembelian Pada Kafe Bangsal Kopi Lubuk Pakam" yang menunjukan variabel harga berpengaruh positif terhadap keputusan pembelian di kedai kopi di Kota Medan. Maka dapat disimpulkan bahwa harga berpengaruh positif dan signifikan terhadap keputusan pembelian.

\section{Lokasi}

Nilai signifikansi variabel lokasi (X7) adalah 0,002 < 0,05, maka H0 ditolak dan Ha diterima, artinya jika variabel lain dianggap tetap, maka variabel lokasi berpengaruh nyata terhadap keputusan pembelian pembelian. Nilai koefisien regresi variabel lokasi (X7) adalah 0,953, artinya apabila lokasi meningkat satu-satuan, maka akan meningkatkan keputusan pembelian sebesar 0,953.

Lokasi merupakan tempat melayani konsumen, dapat pula diartikan sebagai tempat untuk memajangkan barang-barang dagangannya (Kasmir, 2006). Definisi lokasi adalah tempat perusahaan beroperasi atau tempat perusahaan melakukan kegiatan untuk menghasilkan barang dan jasa yang mementingkan segi ekonominya. Menurut Tjiptono (2005), lokasi adalah salah satu kegiatan awal yang harus dilakukan sebelum perusahaan mulai beroperasi, penentuan lokasi yang tepat akan mempengaruhi kemampuan perusahaan dalam melayani konsumen. Keputusan lokasi menyangkut kemudahan akses yang cepat dan dapat menarik sejumlah besar konsumen.

Hasil penelitian ini sesuai dengan penelitian yang dilakukan oleh Anggun Zuhrufanina Azmi (2017) "Pengaruh Store Atmosphere, Harga, Lokasi, Dan Kualitas Produk Terhadap Keputusan Pembelian Konsumen Pada Yellow Truck Coffee And Tea Solo" yang menunjukkan bahwa variabel lokasi berpengaruh positif terhadap keputusan pembelian di Yellow Truck Coffee and Tea Solo. Maka dapat disimpulkan bahwa lokasi berpengaruh positif dan signifikan terhadap keputusan pembelian di kedai kopi di Kota Mataram.

\section{Kualitas Produk}

Nilai signifikansi variabel kualitas produk (X8) adalah sebesar 0,009 $<0,05$, maka H0 ditolak dan Ha diterima, artinya jika variabel lain dianggap tetap, maka variabel kualitas produk berpengaruh nyata terhadap keputusan pembelian. Nilai koefisien regresi variabel kualitas produk (X8) adalah sebesar 0,875, artinya apabila kualitas produk meningkat satu-satuan, maka akan meningkatkan keputusan pembelian sebesar 0,875 .

Apabila dalam situasi pemasaran yang semakin ketat persaingannya, peranan kualitas produk akan semakin besar dalam perkembangan perusahaan. Selain itu, konsumen akan menyukai produk yang menawarkan kualitas, kinerja, dan pelengkap 
inovatif yang terbaik (Lupiyoadi dan Hamdani, 2006). Hal ini sesuai dengan pendapat Kotler dan Amstrong (2008) bahwa semakin baik kualitas produk yang dihasilkan maka akan memberikan kesempatan kepada konsumen untuk melakukan keputusan pembelian. Dalam penelitian ini, kualitas produk dikatakan semakin baik jika produk tersebut memenuhi empat indikator yaitu: rasa kopi yang disajikan nikmat, porsi yang diberikan sesuai dengan harga, banyak variasi menu, dan penyajian higienis.

Hasil penelitian ini sesuai dengan penelitian yang dilakukan oleh Azmi (2017) "Pengaruh Store Atmosphere, Harga, Lokasi, Dan Kualitas Produk Terhadap Keputusan Pembelian Konsumen Pada Yellow Truck Coffee And Tea Solo" yang menyatakan bahwa variabel kualitas produk berpengaruh positif terhadap keputusan pembelian di Yellow Truck Coffee and Tea Solo. Maka dapat disimpulkan bahwa kualitas produk berpengaruh positif dan signifikan terhadap keputusan pembelian di kedai kopi di Kota Mataram.

\section{Hasil Uji F}

Uji statistik F digunakan untuk mengetahui apakah semua variabel independen secara bersama-sama memiliki pengaruh nyata terhadap variabel dependen. Berdasarkan hasil uji F dengan SPSS, didapatkan hasil sebagai berikut:

\begin{tabular}{llllll}
\multicolumn{5}{c}{ Tabel 2. Hasil Uji F } \\
\hline Model & $\begin{array}{l}\text { Sum of } \\
\text { Square }\end{array}$ & DF & Mean Square & F & Sig \\
\hline Regression & 5720.394 & 8 & 715.049 & 25.423 & .000 \\
Residual & 2559.446 & 91 & 28.126 & & \\
Total & 8279.840 & 99 & & & \\
\hline
\end{tabular}

Diketahui nilai $\mathrm{F}_{\text {tabel }}$ dengan $\alpha=0,05$ adalah 2,31 sedangkan nilai $\mathrm{F}_{\text {hitung }}$ dari hasil pengolahan data adalah sebesar 25,423, maka $F_{\text {hitung }}>F_{\text {tabel }}$ sehingga secara bersama-sama variabel independen (Jenis Kelamin, Umur, Pendidikan, Pendapata, Store Atmosphere, Harga, Lokasi, dan Kualitas Produk) berpengaruh signifikan terhadap variabel dependen (Keputusan Pembelian).

Hasil Uji Koefisien Determinasi $\left(\mathbf{R}^{2}\right)$

Koefisien determinasi $\left(\mathrm{R}^{2}\right)$ adalah antara nol dan satu. Nilai $\mathrm{R}^{2}$ menunjukkan kemampuan variabel variabel independen dalam menjelaskan variasi variabel dependen. Adapun hasil pengujian koefisien determinasi dengan SPSS yaitu sebagai berikut.

Tabel 3. Hasil Uji Koefisien Determinasi

\begin{tabular}{ccccc}
\hline Model & $\mathrm{R}$ & $\mathrm{R}$ square & $\begin{array}{c}\text { Adjusted R } \\
\text { Square }\end{array}$ & $\begin{array}{c}\text { Std. Error of } \\
\text { the Estimate }\end{array}$ \\
\hline 1 & 0.831 & 0.691 & 0.664 & 5.30337 \\
\hline
\end{tabular}

Berdasarkan tabel 4.9, diperoleh nilai $\mathrm{R}^{2}$ sebesar 0,664 artinya variasi perubahan independen yaitu jenis kelamin, umur, pendidikan, pendapatan, store atmosphere, harga, lokasi dan kualitas produk dapat menjelaskan variabel keputusan pembelian sebesar $66,4 \%$ sedangkan sisanya $33,6 \%$ dijelaskan oleh variabel atau faktor-faktor lain diluar model yang diestimasi. 


\section{KESIMPULAN DAN SARAN}

\section{Kesimpulan}

Berdasarkan hasil penelitian maka dapat diambil kesimpulan bahwa faktorfaktor yang mempengaruhi keputusan pembelian di kedai kopi lokal kota mataram yaitu faktor Umur (X2) Pendidikan (X3) Pendapatan (X4) Store Atmosphere (X5) Harga (X6) Lokasi (X7) dan Kualitas Produk. Sedangkan faktor jenis kelamin (X1) tidak mempengaruhi keputusan pembelian di kedai kopi lokal Kota Mataram.

\section{Saran}

Berdasarkan hasil penelitian di atas, saran yang dapat peneliti berikan adalah Kedai kopi di Kota Mataram sebaiknya selalu memperhatikan faktor store atmosphere untuk menjaga kenyamanan konsumen ketika berbelanja. Beberapa faktor di dalamnya yang membuat konsumen merasa betah ialah suhu ruangan yang sejuk, aroma ruangan yang wangi, serta musik yang dimainkan. Untuk konsumen, sebaiknya lebih banyak berbelanja di kedai kopi lokal daripada frenchise, karena kualitas kopi dan makanan yang mereka berikan tidak kalah baik dan harga yang mereka tawarkan jauh lebih terjangkau.

\section{DAFTAR PUSTAKA}

Azmi, A.S. (2017). Pengaruh Store Atmosphere, Harga, Lokasi, Dan Kualitas Produk Terhadap Keputusan Pembelian Konsumen Pada Yellow Truck Coffee And Tea Solo [Skripsi]. Surakarta.IAIN Surakarta.

Andriani, M. S. Martini. R. Gunanti \& B. Wirjatmadi (2000). Faktor-faktor yang mempengaruhi konsumsi sayur pada anak pra-sekolah. Jurnal Penelitian Medis Eksekta, 1, 45-47.

Kasmir. 2006. Kewirausahaan. PT Raja Grasindo Persada: Jakarta.

Kotler, P. \& Armstrong, G. (2012). Prinsip- Prinsip Pemasaran. Edisi 12. Erlangga. Jakarta.

Lupiyoadi \& Hamdani.( 2006). Manajemen Pemasaran Jasa: Edisi kedua. Penerbit Salemba Empat: Jakarta.

Ma'ruf, H. (2006). Pemasaran Ritel. Gramedia Pustaka Utama: Jakarta.

Melin Meidina Hutauruk. (2016). Pengaruh Store Atmosphere Terhadap Keputusan Pembelian Konsumen Chirurgie Café dan Books Medan [skripsi]. Medan. Universitas Sumatra Utara.

Nassution, H.F. (2017). Pengaruh Faktor Harga, Lokasi dan Kualitas Pelayanan Terhadap Keputusan Pembelian Pada Kafe Bangsal Kopi Lubuk Pakam [Skripsi]. Medan. Universitas Sumatra Utara.

Nurasiah. (2018). Pengaruh Variabel Demografi Dan Budaya Terhadap Minat Menabung Di Bank Syariah Di Kecamatan Purwakarta. Fakultas Ekonomi Bisnis [skirpsi]. Jakarta. UIN Syarifhidayatullah Jakarta. Jakarta.

Nursan, M., \& Septiadi, D. (2020). Penentuan Prioritas Komoditas Unggulan Peternakan di Kabupaten Sumbawa Barat. Jurnal Agribisnis Dan Ilmu Sosial Ekonomi Pertanian, 5(1), 29-34.

Sugiono. (2017). Metode Penelitian Kuantitatif, Kualitatif, dan R\&D. Alfabeta: Bandung.

Tjiptono, F., Chandra \& Gregorius. (2005). Service Quality and Satisfaction. Andi Offset: Yogyakarta. 